Marinela Krstinić Nižić

University of Rijeka

Faculty of Tourism and

Hospitality Management

51410 Opatija, Croatia

marikn@fthm.hr
Zvonimira Šverko Grdić

University of Rijeka

Faculty of Tourism and

Hospitality Management

51410 Opatija, Croatia

zgrdic@fthm.hr
JEL: P25, Q01, Z32

Preliminary communication

https://doi.org/10.51680/ev.34.1.13

Received: September 16, 2020

Revision received: November 13, 2020

Accepted for publishing: December 24, 2020

Maša Trinajstić

University of Rijeka

Faculty of Tourism and

Hospitality Management

Creative Commons Attribution-

NonCommercial-NoDerivatives 4.0 International License

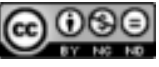

51410 Opatija, Croatia

masat@fthm.hr

\title{
LINKAGE BETWEEN
}

\section{TOURISM AND SUSTAINABLE}

DEVELOPMENT IN URBAN AREAS

\begin{abstract}
Purpose: Over the last decades, tourism has experienced continued growth, and its impact on economic activity can be observed through its effects on the balance of payments and the labour market, as well as connections with other economic activities. According to the ITB report (2016), urban tourism recorded the largest increase, noting that tourist arrivals in urban areas increased by $58 \%$ in the past five years. This was due to growing urbanization, better road accessibility and air connectivity between cities, shorter stays and an increasing number of trips per year. In recent years, the number of tourist arrivals in urban areas has also increased in Croatia. In 2018, over 12 million arrivals were recorded, which represents $64 \%$ of the total tourist arrivals for that year.
\end{abstract}

Methodology: The aim of this paper is to investigate the relationship between tourism (tourism indicators) and sustainable development (investment in sustainable development) in cities in Croatia. The survey covered all 128 cities. The data analysis was conducted using descriptive analysis, correlation analysis, MannWhitney test and regression analysis.

Results: The results show that there is a correlation between tourism and sustainable development in the analysed cities. Cities with thriving tourism pay more attention to sustainable development.

Conclusion: It is necessary to continuously increase the levels of knowledge and understanding of tourism in accordance with the principles of sustainable development.

Keywords: Sustainable development, tourism, urban areas, Croatia

\section{Introduction}

The European Union (EU) has placed much emphasis on the tourism sector as an engine of economic prosperity for its member countries (Lee \& Brahmasrene, 2013), given that the tourism sector does not merely represent a significant stream of revenue, but also a vital source of employment and entrepreneurial vitality. Urban tourism generally has, as is well known, grown significantly in recent decades (IPK International, 2016) and several of the cities in which conflicts have occurred have experienced particularly sharp rises in tourism from often already high levels (Novy, 2019). Urban tourism increased as a result of increased urbanization, better road accessibility and air connectivity 
between cities, shorter stays (so-called city breaks) and an increasing number of trips per year (Ashworth \& Page, 2011). Cities are the greenhouses of ideas, centres of commerce, culture and science, and drivers of economic and social development (Richards \& Palmer, 2010). Cities have enabled people to achieve social and economic advancement (Klopp \& Petretta, 2017). There are, however, many challenges in the management and development of today's smart cities, which often continue generating new jobs and prosperity, without concerns regarding land and resources (Yigitcanlar \& Kamruzzaman, 2018). Common urban challenges include traffic congestion, high energy expenditure, inadequate waste management, lack of resources for providing basic services, lack of adequate housing, and infrastructural issues (Chandan \& Kumar, 2019). These challenges for cities can be overcome in a manner that will enable further improvement and growth, by improving resource management and reducing pollution and poverty (United $\mathrm{Na}$ tions, 2018). Since the beginning of the $21^{\text {st }}$ century, the criteria for a sustainable city or city suitable for human living have become based on a healthy environment, social and cultural sustainability, efficient infrastructure, effective communication and dialogue among all stakeholders participating in decision making, and encouraging innovation and creativity as the framework for sustainable development (United Nations, 2019a; Krstinić Nižić et al., 2019). That is why today, the issue of raising awareness and knowledge on sustainable development can be equated to the issue of our civilization's survival. As the topic of this paper is exceptionally broad, the paper simply provides an overview of particular elements of sustainable development on the example of analysed cities in Croatia. Most of the cities in the Republic of Croatia, especially in the coastal area, are recognized as tourist destinations and tourism is the most important economic activity. Therefore, the aim of this paper is to analyse the impact of tourism activities on sustainable development in urban areas in Croatia. The research question to be asked is whether tourism as a driver of the city's overall development contributes to the greater concern for the sustainable development of cities. Is tourism sufficient to make a city an attractive place to live in? In times of intensive economic, sociological and cultural changes, tourism destination management needs to recognize and define a suitable and feasible model, methodology and the means of implementing an urban destination devel- opment strategy. In the paper, we therefore propose one main hypothesis on the example of 128 cities in Croatia:

H1: Cities that develop tourism show a greater degree of sustainable development.

Development as a socio-economic category is a multidimensional and dynamic process, and it is sometimes difficult to make a distinction between the subject and the object of development. There is no universal definition of development, thus there is no single international standard for measuring and monitoring it. In the context of city development, tourism implies total socio-economic changes sparked by planned and targeted public policies with the aim of shifting the current state towards the desired state. Various scientific methods were used for the purpose of this paper, primarily the desk research method, where relevant data were gathered from the scientific and professional literature and national statistics publications. The data were drawn from the databases of the Ministry of Finance (2019) $)^{1}$, the Croatian Bureau of Statistics $(2019)^{2}$ and the websites of the selected cities.

The paper is organized as follows - after the introduction, the second section describes the available literature. The third section describes the research methodology and statistical analysis. The fourth section presents the research results and the discussion, and the final section is the conclusion. The final chapter also presents the limitations of this research and provides recommendations for future research.

\section{Literature review}

Over the previous decades, tourism has noted a significant expansion and continued growth. Due to its economic impact, it holds a significant position in many countries' economies. In addition to its role in job and wealth creation, the regeneration of urban fabric, and the progressive elimination of inequality between west and east, tourism can contribute to place promotion and economic restructuring (Coles, 2003). Cities have been recognised as tourist destinations long ago, and various authors make a distinction between different types of urban destinations. Spirou (2011) identifies three basic types of urban tourist destinations: urban

\footnotetext{
1 Ministry of Finance, available at: www.mfin.hr

2 Croatian Bureau of Statistics, available at: www.dzs.hr
} 
settlements, tourist-historic cities and rebranded cities, while Page and Hall (2003) distinguish between historical, cultural, business, sports, nightlife, shopping and tourist cities. Authors Smolcic Jurdana and Susilovic (2006) state that a city should be viewed as a multifunctional area that is used by a large portion of the local population as well as by various segments of tourists with differing references, expectations and reasons for travel. Authors Edwards, Griffin and Hayllar (2008) find that urban tourism is distinguishable from other forms of tourism by a number of features which, while not applicable to all urban destinations and possibly applicable to some non-urban destinations, characterize urban tourism destinations as a whole. Cities have recorded a significant increase in tourist arrivals and overnight stays (Ashworth \& Page, 2011). This can be traced to the process of increased urbanisation, better road and air transport connectivity, shorter stays when traveling and a rising number of annual trips (UNWTO, 2011). Authors Ajdin and Rmeksiz (2018) described the relationship between the success factors of sustainable urban tourism and the economic performance of STEs. Within this context, positively significant correlations were found in all causal relationships foreseen between them. In order to examine tourism at the small city level, authors Burnett, Cutler and Thresher (2007) used the CGE model. They found that household migration and commuting play important roles in economic outcomes. Authors Novy and Colomb (2019) critically reviewed the discussions about the variety of tourism-related social mobilisations recently witnessed in cities. Romero-García et al. (2019) explored the extent of available literature on urban tourism that uses a systematic approach. They concluded that the literature mostly focused on the development of urban tourism and its territory (cities), as well as on how the phenomenon of globalisation has affected it, both negatively in the sense of destination homogenisation and positively by achieving urban space diversification. Authors Tokarchuk et al. (2017) focused on the effects of city tourism on the well-being of urban residents. To address this issue, they studied the effect of tourist overnight stays on urban resident satisfaction in centres of cultural tourism. The phenomenon of urban tourism hypertrophy in the context of the process of the formation of tourism-related social conflicts was analysed by authors Zmyślony and Kowalczyk-Anioł (2019). They also analysed the extent to which destination management organiza- tions are prepared to take responsibility and actions with regard to this process.

On the other hand, various organisations, institutions, policies and programmes are focused on sustainable urban development. At the conference in Johannesburg in 2002, various measures and actions were adopted, focused on ensuring sustainable urban development with an emphasis on appropriate quality of life in urban areas (United Nations, 2002). The Treaty of Amsterdam enforces promoting sustainable development as one of the primary goals of the European Union. Similarly, the European Union has developed an initiative for smart and sustainable cities (European Commission, 2019), while the 2030 Agenda for Sustainable Development promotes accessibility, integration, security and sustainability of cities (United Nations, 2015).

However, in order for the approach to sustainable tourism to be feasible, it is necessary to include partners from the tourism industry, local government and community, as well as non-government organizations with various interests, goals, values and perspectives (Timur \& Getz, 2008). Success depends on mutual communication, cooperation and understanding between all stakeholders.

The discussion of sustainable development in Croatian cities has intensified over the recent period. The issue is linked with demographic trends, geographical features and economic activities within cities (Ribić et al., 2017; Krstinić Nižić \& Zubović, 2016; Mirkov, 2012). While cities generate many problems, they also need to be resolved in cities. Additionally, urban issues cannot be fully separated from regional issues. Cities greatly depend on natural resources, and the flow of natural resources depicts the interdependence of economic and demographic changes. City management faces many challenges in situations when human, technical and financial resources are limited (McCann \& OrtegaArgiles, 2015; Boschma, 2016). Urban policies have to be based on an integral approach to management focused on intersectoral communication and cooperation, while monitoring and evaluation of the success of city policies should be a fundamental part (Horvat \& Pavković, 2013). In such a framework, a system of sustainable indicators becomes essential. Criticism regarding the methods of developing indicators primarily aims at developing an indicator which should encompass all aspects of development, including environmental, economic, social, technological, etc. (Perišić \& Wagner, 2015). 
Today, most authors agree that it is not possible to define one single indicator which can cover all dimensions (Huovila et al., 2019; Garau \& Pavan, 2018; Huenting \& Reijnders, 2004). This paper takes into account a part of tourism indicators such as the number of tourist overnight stays, tourist arrivals, tourism intensity and average length of stay, as well as sustainable development indicators such as cities' investments in environmental protection, housing, community development and education. The data have been acquired from the websites of selected cities detailing their budgets. The data should assist city management in measuring the success of its policies in formulating strategic development goals.

\section{Research methodology}

Through the Strategy for Sustainable Development of the Republic of Croatia (2009), Croatia has set the guidelines for sustainable development based on the goals and principles of sustainable development. The Strategy for Sustainable Development of the Republic of Croatia is focused on eight key areas, which imply specific general goals. These are:

- Population - to support population growth in the Republic of Croatia;

- Environment and natural goods: preservation, protection and sustainable management of goods;

- Sustainable production and consumption: focus on vital, sustainable production and balanced consumption;

- Social cohesion and justice: achieving social and territorial cohesion and justice;

- Energy: achieving energy independence and an increase in the efficiency of energy use;

- Public healthcare: strengthening of public healthcare;

- Connecting Croatia: further increase in connectivity within Croatia and with the neighbourhood;

- Protection of the Adriatic Sea, coast and islands.

These are eight essential challenges of sustainable development which are also the basis of the strategic development of Croatia. These goals are narrowly connected with sustainable urban development. Cities have to focus on spatial planning, revitaliza- tion and repurposing of derelict urban land (urban regeneration), healthcare and social protection and equality, education, environmental protection and securing a better quality of life. Sustainable development policies have to be implemented in other sectors' policies, especially tourism.

\subsection{Data description}

As a member of the European Union, Croatia is divided into two statistical NUTS 2 regions - Continental and Adriatic Croatia. Based on this classification, the Republic of Croatia (country) is at NUTS 1 level, and counties are at NUTS 3 level. For the purpose of effective planning, adjustment and implementation of urban development policies in Croatia, the guidelines of the Strategy of Regional Development of the Republic of Croatia define three types of cities - urban agglomerations, larger urban areas and smaller urban areas. Similarly, the Law on Local and Regional Self-Government (NN 33/01, 60/01, 129/05, 109/07, 125/08, 36/09, 36/09, $150 / 11,144 / 12,19 / 13,137 / 15,123 / 17,98 / 19)$ prescribes that large cities have a population greater than 35 thousand citizens, while medium cities have a population between 10 and 35 thousand citizens. There are 127 cities in Croatia and the city of Zagreb which has a special status of both city and county. Since the paper investigates urban areas, all cities were included in the research sample. The data cover the period from 2010 to 2018 . The database used in this paper was generated by drawing on the databases of the Croatian Ministry of Finance, Croatian Bureau of Statistics, and data available on the cities' websites. The Ministry of Finance's database contains a score of indicators pertaining to the execution of city budgets measuring types of income, types of expenditures, and investments in sustainable development through environmental protection, improvement of housing and the community, and education.

In order to analyse the impact of tourism indicators on sustainable urban development in the selected cities, 7 indicators were analysed: average number of tourist overnight stays, average number of tourist arrivals, tourism intensity (the ratio of the number of overnight stays and number of inhabitants), average length of stay, average investments in environmental protection per capita, average investments in housing and the community per capita, and average investments in education per capita. The Mann-Whitney test was used to determine if there were statistically significant differences between cities considering these indi- 
cators. The differences were examined taking into account the two regions (Continental and Adriatic Croatia). Next, the Spearman correlation coefficient was used to examine the correlation between tourism indicators and sustainable development indicators. Additionally, a regression analysis was conducted to estimate the relationships between variables. The analysis was conducted using the Stata 14.2 software.

\subsection{Statistical analysis}

The descriptive statistics is presented in Table 1. The data presented in the following table describe tourism indicators as well as sustainable development indicators in Croatian cities.

Table 1 Descriptive statistics

\begin{tabular}{|l|c|c|c|c|c|}
\hline Variable & Obs & Mean & Std. Dev. & Min & Max \\
\hline Number of tourist overnight stays & 128 & $295,793.80$ & $606,199.60$ & 0 & $3,173,699$ \\
\hline Number of tourist arrivals & 128 & $66,704.09$ & $150,685.60$ & 0 & 990,871 \\
\hline Tourism intensity & 128 & 30.3020 & 62.9327 & 0 & 313.75 \\
\hline Length of stay & 128 & 3.3593 & 1.8979 & 0 & 8 \\
\hline Investments in environmental protection per capita & 128 & 235.878 & 248.865 & 0 & $1,499.88$ \\
\hline Investments in housing and community per capita & 128 & 829.9237 & 658.3376 & 2.96 & $3,111.37$ \\
\hline Investments in education per capita & 128 & 436.0783 & 307.2954 & 87.35 & $1,708.24$ \\
\hline
\end{tabular}

Source: Authors' calculations

The total number of observations is 128 . The average number of tourist overnight stays in the observed cities was almost 300 thousand and the average number of arrivals was 66,704. Average length of stay was 3.3 days, while the highest was 8 days.
The highest tourism intensity was 313.75 . The largest investments per capita were recorded in housing and community, over 3 thousand HRK.

The following table presents differences between cities considering the tourism indicators.

Table 2 The results of Mann-Whitney test (differences considering the region)

\begin{tabular}{|l|c|c|}
\hline Variable & $\mathbf{z}$ & $\mathbf{p}$ - value \\
\hline Number of tourist overnight stays & -7.076 & 0.0000 \\
\hline Number of tourist arrivals & -6.367 & 0.0000 \\
\hline Tourism intensity & -8.159 & 0.0000 \\
\hline Length of stay & -7.679 & 0.0000 \\
\hline
\end{tabular}

Source: Authors' calculations

The results indicate that there are statistically significant differences between the cities of Continental and Adriatic Croatia when it comes to all tourism indicators. According to selected indicators, Adriatic cities are much more developed. The average numbers in the cities of Adriatic Croatia are 590,696 overnight stays and 119,700 arrivals, while in Continental Croatia the average number of overnight stays is 35,585 , and the average number of arrivals is 19,942 . The average length of stay in
Adriatic Croatia is 4.68 days, while in Continental Croatia it is 2.19 days. Regarding tourism intensity, the average intensity in Adriatic Croatia is 63.81 and in Continental Croatia it is 0.73. It can be concluded that the Adriatic cities are in a significant phase of tourist development.

Table 3 shows the correlation analysis, i.e. correlation between selected variables for the cities of Adriatic Croatia. 
Table 3 Spearman correlation coefficient for the cities of Adriatic Croatia $(n=60)$

\begin{tabular}{|c|c|c|c|c|}
\hline Variable & $\begin{array}{l}\text { Number of tourist } \\
\text { overnight stays }\end{array}$ & $\begin{array}{l}\text { Number of } \\
\text { tourist arrivals }\end{array}$ & $\begin{array}{l}\text { Tourism } \\
\text { intensity }\end{array}$ & $\begin{array}{l}\text { Length of } \\
\text { stay }\end{array}$ \\
\hline $\begin{array}{l}\text { Investments in environmental protection per } \\
\text { capita }\end{array}$ & $\begin{array}{c}0.3006 \\
(\mathrm{p}=0.0196)\end{array}$ & $\begin{array}{c}0.2726 \\
(\mathrm{p}=0.0351)\end{array}$ & $\begin{array}{c}0.3951 \\
(\mathrm{p}=0.0018)\end{array}$ & $\begin{array}{c}0.2396 \\
(\mathrm{p}=0.0652)\end{array}$ \\
\hline $\begin{array}{l}\text { Investments in housing and community per } \\
\text { capita }\end{array}$ & $\begin{array}{c}0.5038 \\
(\mathrm{p}=0.0000)\end{array}$ & $\begin{array}{c}0.4446 \\
(\mathrm{p}=0.0004)\end{array}$ & $\begin{array}{c}0.6309 \\
(\mathrm{p}=0.0000)\end{array}$ & $\begin{array}{c}0.5081 \\
(\mathrm{p}=0.0000)\end{array}$ \\
\hline Investments in education per capita & $\begin{array}{c}0.5921 \\
(\mathrm{p}=0.0000)\end{array}$ & $\begin{array}{c}0.5660 \\
(\mathrm{p}=0.0000)\end{array}$ & $\begin{array}{c}0.5220 \\
(\mathrm{p}=0.0000)\end{array}$ & $\begin{array}{c}0.2449 \\
(\mathrm{p}=0.0594)\end{array}$ \\
\hline
\end{tabular}

Source: Authors' calculations

The results obtained through the correlation analysis indicate that there is a link between tourism indicators and all types of investments. Spearman's correlation coefficient shows that there is a weak positive correlation between the number of overnight stays, the number of arrivals and tourism intensity, and investments in environmental protection. A moderate positive correlation is visible between all tourism indicators and investments in housing and community. As the number of tourist overnight stays and arrivals increases, so do investments in environmental protection, housing and community, and education.

The table below shows the correlation for the cities in Continental Croatia.

Table 4 Spearman correlation coefficient for the cities of Continental Croatia $(n=68)$

\begin{tabular}{|l|c|c|c|c|}
\hline Variable & $\begin{array}{c}\text { Number of tourist } \\
\text { overnight stays }\end{array}$ & $\begin{array}{c}\text { Number of } \\
\text { tourist arrivals }\end{array}$ & $\begin{array}{c}\text { Tourism } \\
\text { intensity }\end{array}$ & $\begin{array}{c}\text { Length of } \\
\text { stay }\end{array}$ \\
\hline $\begin{array}{l}\text { Investments in environmental protection per } \\
\text { capita }\end{array}$ & $\begin{array}{c}0.0541 \\
(\mathrm{p}=0.6615)\end{array}$ & $\begin{array}{c}0.0518 \\
(\mathrm{p}=0.6746)\end{array}$ & $\begin{array}{c}0.0235 \\
(\mathrm{p}=0.8493)\end{array}$ & $\begin{array}{c}-0.0203 \\
(\mathrm{p}=0.8694)\end{array}$ \\
\hline $\begin{array}{l}\text { Investments in housing and community per } \\
\text { capita }\end{array}$ & $\begin{array}{c}0.2901 \\
(\mathrm{p}=0.0164)\end{array}$ & $\begin{array}{c}0.3014 \\
(\mathrm{p}=0.0125)\end{array}$ & $\begin{array}{c}0.2492 \\
(\mathrm{p}=0.0405)\end{array}$ & $\begin{array}{c}0.0038 \\
(\mathrm{p}=0.9754)\end{array}$ \\
\hline $\begin{array}{l}\text { Investments in education per capita } \\
\text { ( }\end{array}$ & $\begin{array}{c}0.4049 \\
(\mathrm{p}=0.0006)\end{array}$ & $\begin{array}{c}0.1930 \\
(\mathrm{p}=0.0001)\end{array}$ & -0.2588 \\
$(\mathrm{p}=0.0331)$
\end{tabular}

Source: Authors' calculations

From the above table it can be seen that there is a weak positive correlation between the number of overnight stays, number of arrivals and tourism intensity and investments in housing and community development. A moderate positive correlation is visible between the number of tourist overnight stays and arrivals and investments in education. There is no correlation between tourism indicators and investments in environmental protection.

Based on the conducted analysis, it can be concluded that there is a correlation between tourism indicators and all types of investments in the cities of Adriatic Croatia. In most of those cities, tourism is the leading economic activity, which results in a higher degree of concern for sustainable develop- ment, destination and environmental preservation, housing and education, which in turn contributes to a higher quality of life for residents and visitors. In cities of Continental Croatia, there is a correlation between the number of overnight stays and the number of arrivals and investments in housing and community, as well as investments in education. Tourism activity has been present in these cities in the last several years while some of the cities are only in the initial phase of tourism development.

Regression analysis was used to further examine the relationship between variables. The impact of tourism indicators on the analysed investments was examined based on the conducted correlation analysis. 
Table 5 Regression analysis of selected indicators for the cities of Adriatic Croatia

\begin{tabular}{|l|c|c|c|c|c|c|}
\hline & $\begin{array}{c}\text { Overnight } \\
\text { stays (coef.) }\end{array}$ & $\mathbf{R}^{\wedge} \mathbf{2}$ & p-value & $\begin{array}{c}\text { Arrivals } \\
\text { (coef.) }\end{array}$ & $\mathbf{R}^{\wedge} \mathbf{2}$ & $\mathbf{p}$-value \\
\hline $\begin{array}{l}\text { Investments in environmental protec- } \\
\text { tion per capita }\end{array}$ & 0.0001384 & 0.1006 & 0.014 & 0.0006184 & 0.0946 & 0.017 \\
\hline $\begin{array}{l}\text { Investments in housing and commu- } \\
\text { nity per capita }\end{array}$ & 0.0004414 & 0.2088 & 0.000 & 0.0016786 & 0.1422 & 0.003 \\
\hline Investments in education per capita & 0.0002053 & 0.1977 & 0.000 & 0.0008386 & 0.1553 & 0.002 \\
\hline
\end{tabular}

Source: Authors' calculations

The analysis of regression parameters shows a significant effect of both parameters on all types of investments. If the average number of overnight stays increases by 1 , average investments in environmental protection per capita will increase by 0.0001384
HRK, in housing and community per capita by 0.0004414 HRK and in education per capita by 0.0002053 HRK. Additionally, increasing the average number of tourist arrivals in a city also results in higher investments in sustainable development.

Table 5 Regression analysis of selected indicators for the cities of Continental Croatia

\begin{tabular}{|l|c|c|c|c|c|c|}
\hline & $\begin{array}{c}\text { Overnight stays } \\
\text { (coef.) }\end{array}$ & $\mathbf{R}^{\wedge} \mathbf{2}$ & $\mathbf{p}$-value & $\begin{array}{c}\text { Arrivals } \\
\text { (coef.) }\end{array}$ & $\mathbf{R}^{\wedge} \mathbf{2}$ & $\mathbf{p}$-value \\
\hline $\begin{array}{l}\text { Investments in housing and commu- } \\
\text { nity per capita }\end{array}$ & 0.0000797 & 0.1828 & 0.000 & 0.0013632 & 0.1853 & 0.000 \\
\hline Investments in education per capita & 0.0006309 & 0.2876 & 0.000 & 0.0010765 & 0.2901 & 0.000 \\
\hline
\end{tabular}

Source: Authors' calculations

The analysis of regression parameters shows a significant impact of the average number of overnight stays and arrivals on investments in housing and community as well as education. If the average number of overnight stays increases by 1 , average investments in housing and community will increase by $0,0000797 \mathrm{HRK}$ and in education by 0,0006309 HRK.

\section{Results and discussion}

The results of the research provide an insight into the state of sustainable development in Croatian cities, taking into consideration the fact that tourist overnight stays affect sustainable development. By analysing the obtained results, it can be concluded that in the cities of Adriatic and Continental Croatia there is a correlation between tourism and sustainable development. However, a stronger correlation was found for Adriatic cities, where the correlation of almost all tourism indicators (except the length of stay) and the indicators of sustainable development is visible. Additionally, the results indicate that an increase in overnight stays and arrivals increases city investments in improving en- vironmental protection, housing and community, and education. It can be concluded that cities with thriving tourism invest more in sustainable development, i.e. in Adriatic cities there is a greater inflow of financial resources from tourism, which allows investments in sustainable development. In the cities of Continental Croatia, there is weaker correlation between tourism and sustainable development. Most of these cities have begun developing tourism in recent years and some of them are still in the initial phase of tourism development. They therefore have lower tourist demand so the influx of tourists is not such as to adversely affect the local population and sustainable development. However, it is important that all cities embrace the concept of sustainable development in tourism, invest in environmental protection and preservation and the quality of life of their citizens. It is important to strive towards all cities in Croatia being focused on achieving sustainable development. This includes using all available tools for environmental protection, social justice and economic sustainability regardless of their size, development status, capacities and other regional specificities. Cities have various domestic and international sources 
of funding at their disposal for urban sustainability projects. Some cities were unsuccessful in drawing funds, which resulted in a lack of human resources for preparing and implementing projects, a lack of funding for projects, unresolved ownership issues, etc. Some of these obstacles can be overcome on the local level by hiring new or training existing public servants, modernizing city administration, designing the necessary strategies and preparing project documentation in a timely manner. Cities need to invest more effort and work on improving the employment process, open new jobs on the labour market, including for people with disabilities and others with employability issues. It is necessary to enhance the quality of services and life in general in the city, improve infrastructure and public transportation, and open new jobs which can contribute to society's sustainability. There is a constant need for raising awareness and educating citizens on sustainable development by supporting changes in citizens' behaviour (Li et al., 2019; Krstinić Nižić et al., 2019; Yang et al., 2017).

In order to meet the growing needs of citizens in tourist destinations and solve problems related to the increase of urban populations, city managements have to consider innovative approaches to achieving sustainable development. Developing sustainable cities is a way to prevent population drain and address environmental issues through an integrated approach, because many components of natural ecosystems are intertwined with components of social, economic, cultural and political urban systems to form a singular system (Shaker \& Sirodoev, 2016; Zamfir \& Corbos, 2015; Dias et al., 2014).

It is therefore necessary to improve the efficiency of all aspects of city services, including public and municipal services, which is essential for securing a higher degree of the system's economic efficiency and consequently securing a better life for citizens. Each city represents a unique system where different participants - local government, businesses, and citizens - conduct many activities, and create complex interactions and interdependencies. Taking into consideration that tourism impacts the ecological and social context of a city, its priorities, as well as its history and specific features, it is necessary to implement a strategic urban plan that can help the authorities to find the optimal route towards the final goal - a sustainable city. The hypothesis that tourism contributes to the implementation of the concept of sustainable development can be confirmed. The paper analysed 128 cities in the Republic of Croatia, given that cities have been recognized as popular tourist destinations that are seeing a significant rise in tourism arrivals and overnight stays.

\section{Conclusions}

Cities in the Republic of Croatia should adopt measures for sustainable development as the best and most appropriate solution for increasing their citizens' well-being. It is necessary to learn from the experiences of others at both local and global levels. Strategic and long-term planning is paramount in order to achieve a sustainable future. Given the seasonal nature of tourism in Croatia, in the summer months there is pressure on space and the environment, which is why it is necessary to increase the knowledge and understanding of the principles of sustainable development in addition to building the skills required to implement them. The solution involves changing policies on the local, national and global levels, as well as changing citizens' habits.

It can be concluded that it is necessary to continuously increase the levels of knowledge and understanding of tourism in accordance with the principles of sustainable development. Tourism has become one of the most relevant spatial-geographic phenomena, and in addition to industrialization and urbanization represents the largest strain on space. The physical effect of tourism on the environment does not only manifest through pollution, but also through overconsumption of resources. It is therefore necessary to change how we think, which involves active cooperation among all stakeholders in tourism, citizens and local government. Citizens should be better informed, and awareness raised of the importance of the sustainable use and preservation of the environment and natural resources, which also includes encouraging people to change existing behavioural patterns. This means that the patterns for the sustainable production and consumption should be implemented on all levels corporate, social, and personal.

The scientific contribution of the paper is manifested in the confirmation of the correlation between tourism and sustainable development in cities in the Republic of Croatia. The authors proved a strong correlation between tourism and sustainable development in the cities of Adriatic Croatia, while a weaker correlation was proven to exist in the cities of Continental Croatia. Each new scientific paper constitutes a contribution in the theo-

182 — EKONOMSKI VJESNIK / ECONVIEWS — Vol. 34, No. 1 (2021), pp. 175-186 
retical sense as it provides researchers with the opportunity to expand the body of knowledge on this subject, and at the same time, it provides decision makers on the local level the opportunity to assess their own knowledge about the sustainable development in urban areas. Researchers and managers can use these results to consider the necessary actions in terms of investments, environmental protection, training, and other aspects of sustainable development in accordance with the specificities of urban areas.

Finally, it is necessary to point out the limitations of this research, primarily the fact that the analysis in- cluded specific indicators and only cities in the Republic of Croatia. Our recommendation for further research is to make a comparison with similar cities across the European Union, as well as conduct primary research in the form of polls or interviews with citizens or local decision makers.

\section{Acknowledgements}

This paper has been fully supported by the University of Rijeka under the project number "uniridrustv-18-212". 


\section{REFERENCES}

1. Ashworth, G. \& Page, S. J. (2011). Urban tourism research: Recent progress and current paradoxes. Tourism Management, 32(1), 1-15. https://doi.org/10.1016/j.tourman.2010.02.002

2. Aydin, B. \& Emeksiz, M. (2018). Sustainable urban tourism success factors and the economic performance of small tourism enterprises. Asia Pacific Journal of Tourism Research, 23(10), 975-988. https://doi.org/10.1080/10941665.2018.1513049

3. Boschma, R. (2016). Smart Specialisation and Regional Innovation Policy. Welsh Economic Review, 24(Spring), 17. https://doi.org/10.18573/j.2016.10050

4. Burnett, P., Cutler, H. \& Thresher, R. (2007). The impact of tourism for a small city: a CGE approach. Journal of Regional Analysis and Policy, 37(3), 233-242.

5. Chandan, S. \& Kumar, A. (2019). Challenges for urban conservation of core area in pilgrim cities of India. Journal of Urban Management, 8(3), 472-484. https://doi.org/10.1016/j.jum.2019.05.001

6. Coles, T. (2003). Urban tourism, place promotion and economic restructuring: the case of post-socialist Leipzig. Tourism Geographies, 5(2), 190-219. https://doi.org/10.1080/1461668032000068306

7. Dias, N., Curwell, S. \& Bichard, E. (2014). The current approach of urban design, its implications for sustainable urban development. Procedia Economic and Finance, 18(1), 497-504. https://doi.org/10.1016/S2212-5671(14)00968-X

8. Edwards, D., Griffin, T. \& Hayllar, B. (2008). Urban tourism research: developing an agenda. Annals of Tourism Research, 35(4), 1032-1052. https://doi.org/10.1016/j.annals.2008.09.002

9. European Commission (2016). Smart Cities and Communities. http://ec.europa.eu/eip/smartcities

10. Garau, C. \& Pavan, V. M. (2018). Evaluating urban quality: Indicators and assessment tools for smart sustainable cities. Sustainability, 10(3), Art. 575. https://doi.org/10.3390/su10030575

11. Horvat, J. \& Pavković, M. (2013). Physical Planning and Programming Agenda - Mapping and Programming Spatial Potentials as a Basis for Integral Development. Prostor: A Scholarly Journal of Architecture and Urban Planning, 21(2), 292-301.

12. Huenting, R. \& Reijnders, L. (2004). Broad sustainability contra sustainability: the proper construction of sustainability indicators. Ecological Economics, 50(3-4), 249-260.

https://doi.org/10.1016/j.ecolecon.2004.03.031

13. Huovila, A., Bosch, P. \& Airaksinen, M. (2019). Comparative analysis of standardized indicators for Smart sustainable cities: What indicators and standards to use and when?. Cities, 89, 141-153. https://doi.org/10.1016/j.cities.2019.01.029

14. IPK International (2016). ITB World Travel Trends Report 2015-2016. Messe Berlin GmbH, Berlin.

15. Klopp, M. J. \& Petretta, D. (2017). The urban sustainable development goal: Indicators, complexity and the politics of measuring cities. Cities, 63, 92-97. https://doi.org/10.1016/j.cities.2016.12.019

16. Krstinić Nižić, M. \& Zubović, N. (2016). Urban ecology as the basis for urban living. Journal of the Polytechnic of Rijeka, 4(1), 45-58.

17. Krstinić Nižić, M., Rudan, E. \& Trinajstić, M. (2019). The role of creative cities in regional development. Business Excellence, 13(1), 35-55. https://doi.org/10.22598/pi-be/2019.13.1.35

18. Krstinić Nižić, M., Trinajstić, M. \& Šverko Grdić, Z. (2019). Towards sustainable cities in Croatia. In Mambretti, S, Miralles \& Garcia, J. L. (Eds.). WIT Transactions on Ecology and the Environment, Sustainable City XIII, Thirteenth International Conference on Urban Regeneration and Sustainability (pp. 443-454). WIT Press.

19. Law on Local and Regional Self-Government (NN 33/01, 60/01, 129/05, 109/07, 125/08, 36/09, 36/09, 150/11, 144/12, 19/13, 137/15, 123/17, 98/19). https://www.zakon.hr/z/132/Zakon-o-lokalnoj-ipodru\%C4\%8Dnoj-(regionalnoj)-samoupravi 
20. Lee, J. W. \& Brahmasrene, T. (2013). Investigating the influence of tourism on economic growth and carbon emissions: Evidence from panel analysis of the European Union. Tourism Management, 38, 6976. https://doi.org/10.1016/j.tourman.2013.02.016

21. Li, R., Peng, L. \& Deng, W. (2019). Resident Perceptions toward Tourism Development at a Large Scale. Sustainability, 11(18), Art. 5074. https://doi.org/10.3390/su11185074

22. McCann, P. \& Ortega-Argiles, R. (2015). Smart specialization, regional growth and applications to European union cohesion policy. Regional Studies, 49(8), 1291-1302. https://doi.org/10.1080/00343404.2013.799769

23. Mirkov, A. (2012). Urban social sustainability: A concept analysis. Sociologija, 54(1), 55-70. https://doi.org/10.2298/SOC1201055M

24. Novy, J. \& Colomb, C. (2019). Urban tourism as a source of contention and social mobilisations: A critical review. Tourism Planning \& Development, 16(4), 358-375. https://doi.org/10.1080/21568316.2019.1577293

25. Novy, J. (2019). Urban tourism as a bone of contention: four explanatory hypotheses and a caveat. International Journal of Tourism Cities, 5(1), 63-74. https://doi.org/10.1108/IJTC-01-2018-0011

26. Page, S. J. \& Hall, C. M. (2003). Managing Urban Tourism. Pearson Education Limited.

27. Perišić, A. \& Wagner, V. (2015). Development index: analysis of the basic instrument of Croatian regional Policy. Financial Theory and Practice, 39(2), 205-236. https://doi.org/10.3326/fintp.39.2.4

28. Ribić, B., Voća, N. \& Ilakovac, B. (2017). Concept of sustainable waste management in the city of Zagreb: Towards the implementation of circular economy approach. Journal of the Air \& Waste Management Association, 67(2), 241-259. https://doi.org/10.1080/10962247.2016.1229700

29. Richards, G. \& Palmer, R. (2010). Eventful Cities: Cultural Management and Urban Revitalisation. Butterworth-Heinemann.

30. Romero-García, L. E., Aguilar-Gallegos, N., Morales-Matamoros, O., Badillo-Piña, I. \& Tejeida-Padilla, R. (2019). Urban tourism: a systems approach-state of the art. Tourism Review, 74(13), 679-693. https://doi.org/10.1108/TR-06-2018-0085

31. Shaker, R. R. \& Sirodoev, I. G. (2016). Assessing sustainable development across Moldova using household and property composition indicators. Habitat International, 55, 192-204. https://doi.org/10.1016/j.habitatint.2016.03.005

32. Smolčic Jurdana, D. \& Sušilović, Z. (2006). Planning city tourism development. Tourism and Hospitality Management, 12(2), 135-144.

33. Spirou, C. (2011). Urban Tourism and Urban Change: Cities in a Global Economy. Routledge. https://doi.org/10.4324/9780203835807

34. Strategy for Sustainable Development of the Republic of Croatia (NN 30/09). https://narodne-novine.nn.hr/clanci/sluzbeni/full/2009_03_30_658.html

35. Timur, S. \& Getz, D. (2008). A network perspective on managing stakeholders for sustainable urban tourism. International Journal of Contemporary Hospitality Management, 20(4), 445-461. https://doi.org/10.1108/09596110810873543

36. Tokarchuk, O., Gabriele, R. \& Maurer, O. (2017). Development of city tourism and well-being of urban residents: A case of German Magic Cities. Tourism Economics, 23(2), 343-359.

https://doi.org/10.1177/1354816616656272

37. United Nations (UN) (2002). Report of the World Summit on Sustainable Development. https://digitallibrary.un.org/record/478154

38. United Nations (UN) (2015). Transforming our world: the 2030 Agenda for Sustainable Development. http://www.un.org/ga/search/view_doc.asp?symbol=A/RES/70/1\&Lang=E

39. United Nations (UN) (2018). Sustainable Cities: Why they matter?

https://www.un.org/sustainabledevelopment/wp-content/uploads/2018/09/Goal-11.pdf 
40. United Nations World Tourism Organization (UNWTO) (2011). Policy and Practice for Global Tourism. http://pub.unwto.org/WebRoot/Store/Shops/Infoshop/4D93/3C61/DDD2/4F6C/8E4C/ C0A8/0164/5C4F/110330_policy_practice_global_tourism_excerpt.pdf

41. Yang, B., Tong X. \& Shi, L. (2017). Analysis on sustainable urban development levels and trends in China's cities. Journal of Cleaner Production, 141, 868-880. https://doi.org/10.1016/j.jclepro.2016.09.121

42. Yigitcanlar, T. \& Kamruzzaman, Md. (2018). Does smart city policy lead to sustainability of cities?. Land Use Policy, 73, 49-58. https://doi.org/10.1016/j.landusepol.2018.01.034

43. Zamfir, A. \& Corbos, R. A. (2015). Towards Sustainable Tourism Development in Urban Areas: Case Study on Bucharest as Tourist Destination. Sustainability, 7(9), 12709-12722. https://doi.org/10.3390/su70912709

44. Zmyślony, P. \& Kowalczyk-Anioł, J. (2019). Urban tourism hypertrophy: who should deal with it? The case of Krakow (Poland). International Journal of Tourism Cities, 5(2), 247-269.

https://doi.org/10.1108/IJTC-07-2018-0051 